V. L. Bezsonnyi ${ }^{1}$, Cand. Sc. (Tech.), orcid.org/0000-0001-8089-7724,

O.V.Tretyakov ${ }^{2}$, Dr. Sc. (Tech.), Assoc. Prof., orcid.org/0000-0002-0457-9553,

V.V.Asotskyi ${ }^{3}$, Cand. Sc. (Psych.), orcid.org/0000-0001-5403-3156,

R. V. Ponomarenko ${ }^{3}$, Cand. Sc. (Tech.), Senior

Research Fellow,

orcid.org/0000-0002-6300-3108
1 - Simon Kuznets Kharkiv National University of Economics, Kharkiv, Ukraine, e-mail: vitalii.bezsonnyi@hneu.net 2 - Kharkiv State Academy of Physical Culture, Kharkiv, Ukraine

3 - National University of Civil Defense of Ukraine, Kharkiv, Ukraine

\title{
PRODUCTION RISK MANAGEMENT IN THE FOUNDRY
}

Purpose. Improving the efficiency of production risk management of a machine-building enterprise unit by: 1) improving the methodology of analysis of existing risks; 2) developing a cost-optimization program for risk management.

Methodology. The study used general scientific and specific research methods: analysis, generalization of scientific experience; risk and hazard assessment was carried out using the method of structured assessment; in solving the problem of cost optimization, the model of "knapsack problem" was used.

Findings. Since production risk management is related to the material costs of the enterprise for occupational safety measures, improving the effectiveness of risk management involves consistently using qualitative and quantitative assessments. The methodology was improved, the dangerous factors were identified and analyzed; the task of optimizing costs in risk management was set and solved.

Originality. The risk management approach is to use an advanced approach to evaluate and use the optimization model. Methodological approaches to risk assessment have been further developed which include the calculation of not only the probability of occurrence. For the first time, to optimize the costs for occupational safety measures in the machine-building enterprise unit, the "knapsack problem" was used, which allows reducing the amount of risk to an acceptable level.

Practical value. The results of the study are embodied in a specific methodology, the use of which allows the optimal way to manage risks in the enterprise unit.

Keywords: risk management, production risk, “knapsack problem” model, machine-building

Introduction. Increasing the level of workers protection against occupational hazards in the course of their employment is one of the main activities of all occupational health professionals, and reducing occupational injuries and occupational diseases remains the most important task of all levels of occupational safety management from all points of view - humanitarian, social and economic, personal, corporate and public ones.

Market economy growth in our country requires a certain change in the organizational mechanisms and methods for occupational risk prevention, prevention of occupational injuries and occupational disease.

At a machine-building factory, departments and workshops engaged in hot metal processing are among the leading ones. Economic state of the enterprise mostly depends on them, because they usually use harvested material, and details go from them to further processing and assembly of the nodes. The work safety level is influenced by technology, location of equipment in the area and its condition, as well as the age and condition of employees, their qualifications, and labour intensity.

At such manufacturing sites, highly toxic chemicals, automatic equipment, flow-mechanized lines, robots and manipulators are widely used; most operations are performed in conditions of high visual tension, dustiness and gassiness.

That is why potential danger of traumatic situations, risk of occupational diseases, and the number of industrial hazards for the health and life of people increase.

Risk is a natural component of life and accompanies people in all spheres of their activity. In some cases, risk can be high and may cause a or industrial accidents, as well as occupational diseases. In other cases, there is less risk and its consequences are not as dangerous, such as minor trauma or minor material damage.

(C) Bezsonnyi V. L., Tretyakov O. V., Asotskyi V. V., Ponomarenko R. V., 2020
Among the risk factors experienced by the modern human, the risk of losing one's health and working capacity as a result of professional activity holds an important place.

In order to prevent injuries and improve the level of occupational safety, a safety management system is introduced at enterprises, which is enshrined in Article 13 of the Ukrainian Law "On Occupational Safety". This requires an employer to create working conditions in each workplace in accordance with the requirements of regulations and to ensure compliance with the requirements of the legislation on a worker's rights in the field of labour protection. The employer is directly responsible for violation of the requirements specified in the Law. However, the implementation of requirements of the Law in practice of management is slow or not professional enough, which hinders effective results. Therefore, there is a need to develop new and improve already existing instruments for implementing the provisions of legislative and regulatory acts on labour protection, and above all it concerns assessment of risks of hazards at an enterprise.

Literature review. Risk management has been considered by many well-known scientists. In [1], regulatory documents on assessment and management of occupational hazards are analysed. The analysis identified problems with objectives, terminology and methodology of the risk assessment procedure. The main stages of overall risk assessment have been analysed and systemic issues have been identified that have a significant impact on quality and objectivity of their implementation, as well as calling into question the practical feasibility of the assessment procedure within the existing standards. Urgency of creating scientific bases for risk assessment of occupational hazards is substantiated, which will greatly simplify the assessment procedure and increase quality and objectivity of its conduct.

The author [2] presented a conceptual model of decisionmaking on management of occupational injury risks by a person responsible for quantifying equivalence of financial relations between an administration of industrial enterprise as a party to an employment contract and an employee in terms of minimizing consequences of occupational injury. In addition, 
it is noted that at this time there are a significant number of models and methods of analysis of occupational injuries [3]. The most common of these include probabilistic-statistical and deterministic groups of methods. The scientific and theoretical base of the research consists of the works of domestic and foreign scientists, namely: Kropyvnytskyi V.S., Ruban O. O., Berezutsky V. V., Kostenko O. M., Venediktova V. S., Gogitashvili G. G., Lysyuk M. O., Miroslav Kelemen, Devysilova V.A. and others. Most authors point to need to model the problems of occupational injuries and their impact on the nature of the relationship between the employee and employer. In [4], methodological developments based on impact of risk factors on the basis of proposed approach to its quantitative evaluation will help to increase the level of reliability of organizational and managerial decisions made in substantiating cost and time indicators of projects in a changing external environment. The work [5] emphasized the need to develop a risk management culture at enterprises as a necessary condition for early identification, assessment and reduction of risks, as well as open communication about risks.

In assessing occupational risks in [6], it was found that a safe area of using filter half-masks in coal mines should be limited to 5 MPC. Calculation of the risk level when using "Risk score" method, showed that at a concentration of coal dust above $20 \mathrm{mg} / \mathrm{m}^{3}$, the presence of dust respirators allows providing only a moderate degree of risk of occupational diseases. In this case, excess of submask dust concentration in the respirator up to $18 \%$ at MPC $2 \mathrm{mg} / \mathrm{m}^{3}$ is recorded. It is noted that the non-use of respirators or their removal for more than five minutes per shift in a constant dusty environment results in an almost threefold increase in dust concentration under the mask.

The article [7] analyses requirements of ISO 9001:2015 and ISO 14001:2015 for risk analysis. The authors [8] have considered theoretical bases of risk management. In [9] it was determined that disruption of exponential nature can be caused by organizational measures aimed at reducing occupational risk indicators. The article [10] proposes an approach to sound planning of preventive measures, based on the use of the Hurwitz criterion, expert assessments and calculated values of production risk. The paper [11] presents data on the current state of occupational injuries in Ukraine. Its dynamics are considered. In the article [12] it is emphasized that the introduction of preconditions and operation organization quality allows considering various factors influencing safety. The purpose of the Article [13] is to find out possibility of determining probability of injuries resulting from industrial accident using methods of probability theory, namely Markov chains. In [14], the possibility of applying the theory of risk to determine level of influence of harmful and dangerous production factors on a working person is analysed. The method of integral risk assessment in work area is proposed, considering stay time of employees in area of hazardous factors, based on the probable model of influence of harmful factors on health of workers. Risk-based approach of dependency can be used to certify jobs, prioritize occupational safety and health measures, considering level of industrial and occupational risks. In economic studies related to assessment of effectiveness of implementation of emergency measures at an enterprise [15], the more typical use of concept of "reversed damage" (defined as expected loss in probability of an accident), which by semantic filling is identical to the concept of "risk".

Risk is generally assessed by a probabilistic characteristic (a dimensionless value from 0 to 1 ), but the use of frequency of risk realization is also possible. Frequency of implementation is the number of cases of possible danger in a given period of time. For example, per year, the measurement units of risk may be [1/ year] or [people/year]. There are two long-established perspectives on risk - the first is based on scientific and technical assessments: the so-called theoretical risk, the second depends on human perception of risk: the so-called effective risk [14].
As can be seen from the analysis of available sources, the issue of risk identification and assessment has received considerable attention, but, as noted in a study [15], there are still no simple and reliable assessment methods that would allow managing it effectively.

Unsolved aspects of the problem. Mechanical Engineering Enterprises make one of the industries with a high level of occupational injuries and occupational diseases, the risk of man-made accidents and catastrophes. In this connection, a question arises of the development of effective risk management techniques taking into account the whole set of socio-economic factors, including those through modelling $[14,16]$.

Purpose. The purpose of the work is to increase the efficiency of production risk management of the machine-building enterprise unit.

To achieve this goal, it is necessary to solve the following problems:

1) to improve the methods for analysing existing risks, to identify them in the foundry shop of "Elektrovazhmash" plant and to classify them;

2) to develop a cost optimization program for risk management based on a convolution tree.

Methods. The theoretical risk is expressed in the form of a statistic, which is often reduced to the probability of some undesirable event. Typically, the probability of such an event and some estimate of expected harm are combined into a single metric that combines a set of risk and harm or reward probabilities. Thus, in the statistical decision-making theory, the risk function $\delta(x)$ for the parameter $\theta$, calculated for some observed parameters $x$, is defined as the mathematical expectation of the loss function $L(\theta, \delta(x))$ [14]

$$
R(\theta)=\int L(\theta, \delta(x)) \cdot f(x \mid \theta) d x,
$$

where $L(\theta, \delta(x))$ is the loss function of the estimation parameter $\theta$ and the estimation value $\delta(x) ; f(x \mid \theta)$ is the probability of an unwanted event.

In practice, as a rule, partial forms of expression (1) are used, which depend on the fact that the dependency is significantly simplified, taking into account the specific conditions of the risk assessment. The probability of an adverse event is determined by the frequency of implementation of the hazards

$$
P=f(x \mid \theta)=\frac{N(t)}{Q(x)},
$$

where $N(t)$ is the number of adverse events in time $t ; Q(x)$ is the total number of events in the system.

For the loss function $L(\theta, \delta(x))$ they usually take some cost unit of risk that characterizes the consequences of an event.

As part of this study, we will focus on the risk assessment methodology outlined in the British Standard BS 8800 and in accordance with the international standard ISO 45001 "Health and Safety Management Systems. Requirements and guidance for application" [17].

The work on hazard identification, risk assessment and risk management has been considered [18]:

- permanent operations for which the workplace is assigned, periodic and occasional operations such as cleaning and repairing, starting and stopping, as well as potential emergencies, consumption of products or services supplied by other organizations;

- activities of all staff having access to the workplace (as well as visitors);

- workplace equipment

The above factors should have been considered in the units in the following situations:

- normal (working) conditions;

- abnormal conditions (start, stop, repair, etc.);

- emergency conditions and incidents. 
After completion of the process of hazard identification and risk assessment, the structural units of the enterprise were fully aware of all the existing and managed occupational hazards.

For hazard identification, a list of jobs was defined in such a way as to get the most accurate idea of the dangers that exist in this structural unit. One or two jobs are selected from jobs with the same nature of work performed and similar working conditions.

Selected jobs of the structural unit represented all types of work performed in the works unit, all professions (especially those related to high risk).

It is mandatory to identify the hazards of those workers who have non-permanent jobs (an electric truck driver, a forklift truck driver, a welder, a loader, a slinger, and others), as well as employees who most often appear in the of health and safety log books as "violators" of industrial discipline.

During observation and interviews with employees, the most important factors affecting workplace safety were identified: the manufacturing process; the content of the workplace; safety at work on production equipment; environmental factors in the workplace; ergonomic factors; passageways and passageways; opportunities for rescue and first aid.

Methodology for structured risk assessment. The initial risk and hazard assessment is performed using the structured assessment method, which is based on the recommendations $[18,19]$, meets the requirements [17], is adapted to the conditions of the enterprise and is as follows.

The risk assessment formula (1), can be written in a simplified form

$$
R=L \cdot P,
$$

where $R$ is risk; $P$ is the indicator characterizing a probability of occurrence of an undesirable event that threatens life, human health, equipment of the enterprise, which is determined by Table 1. In assessing the risks associated with the impact of harmful factors, the probability index is determined by Table 2; $L=k_{1} \cdot k_{2}$, where $k_{1}$ is an indicator characterizing frequency with which workers are exposed to hazard, exposure to harmful and dangerous factors, which is determined by Table $3 ; k_{2}$ is an indicator characterizing the consequences, which is estimated by Table 4.

Based on the value obtained in accordance with Table 5, a risk analysis is conducted and the need for corrective action is determined.

Risks with a score of 100 or higher require development of additional preventive measures. Preventive measures required by law or other mandatory documents are taken regardless of the risk assessment results.

"Knapsack problem" model. There are three risk strategies: risk acceptance, risk avoidance, risk management. It is necessary not to avoid the inevitable risk, but to be able to feel it, to estimate its magnitude and not to go beyond acceptable limits.

Table 1

The indicator characterizing the probability of an adverse event $(\mathrm{P})$, estimated when employees are exposed to hazardous production factors [11, 19]

\begin{tabular}{|c|l|l|}
\hline Value & \multicolumn{1}{|c|}{ Probability } & \multicolumn{1}{|c|}{$\begin{array}{c}\text { The frequency of occurrence } \\
\text { of an undesirable event }\end{array}$} \\
\hline 10 & Very high & Monthly \\
\hline 6 & High & Probable within a week \\
\hline 3 & Average & Probable within a month \\
\hline 1 & Little & Probable within a year \\
\hline 0.5 & Very small & During service life \\
\hline 0.1 & Almost impossible & $\begin{array}{l}\text { It is theoretically possible, yet } \\
\text { practically impossible }\end{array}$ \\
\hline
\end{tabular}

Table 2

The indicator characterizing the probability of an adverse event $(P)$, estimated when employees are exposed to harmful industrial factors

\begin{tabular}{|c|l|c|}
\hline Value & \multicolumn{1}{|c|}{ Probability } & $\begin{array}{c}\text { Exceedance of hygiene } \\
\text { standards, (times) }\end{array}$ \\
\hline 10 & Very high & $>20$ \\
\hline 6 & High & $10.1-20$ \\
\hline 3 & Average & $6.1-10$ \\
\hline 1 & Little & $3.1-6$ \\
\hline 0.5 & Very small & $1.1-3$ \\
\hline 0.1 & Almost impossible & $\leq 1$ \\
\hline
\end{tabular}

Table 3

The indicator characterizing the frequency of impact $\left(k_{l}\right)$

\begin{tabular}{|c|l|l|}
\hline Value & Characteristic & Frequency of work in the danger zone \\
\hline 10 & Constantly & During the shift constantly \\
\hline 6 & Regularly & During the shift periodically \\
\hline 3 & Periodically & Several times a week \\
\hline 2 & Sometimes & Several times a month \\
\hline 1 & Rarely & Several times a year \\
\hline 0.5 & Very rarely & At least once a year \\
\hline
\end{tabular}

Table 4

The indicator characterizing the severity of consequences $\left(k_{2}\right)$

\begin{tabular}{|c|l|l|}
\hline Value & $\begin{array}{c}\text { Consequence } \\
\text { category }\end{array}$ & \multicolumn{1}{|c|}{$\begin{array}{c}\text { Characteristic of severity of } \\
\text { consequences }\end{array}$} \\
\hline 40 & A major accident & Group Accident (two or more deaths) \\
\hline 15 & Very significant & One fatal case \\
\hline 7 & Significant & Disability, persistent disability \\
\hline 3 & Serious & Temporary or partial disability \\
\hline 1 & Minor & $\begin{array}{l}\text { Minor injuries, with providing first } \\
\text { aid without any disability }\end{array}$ \\
\hline
\end{tabular}

Table 5

Risk analysis and recommended actions

\begin{tabular}{|c|l|l|}
\hline $\begin{array}{c}\text { The value } \\
\text { of } R\end{array}$ & \multicolumn{1}{|c|}{$\begin{array}{c}\text { Risk } \\
\text { characteristics }\end{array}$} & \multicolumn{1}{c|}{ Corrective actions } \\
\hline $\begin{array}{c}\text { More } \\
\text { than } 400\end{array}$ & $\begin{array}{l}\text { Very High } \\
\text { (unacceptable) }\end{array}$ & $\begin{array}{l}\text { Work should be stopped or not } \\
\text { started until the risk is reduced }\end{array}$ \\
\hline $300-400$ & High & $\begin{array}{l}\text { An order of organization of work } \\
\text { should be developed, measures to } \\
\text { reduce risk within a period not } \\
\text { exceeding three months are to be taken }\end{array}$ \\
\hline $100-300$ & Considerable & $\begin{array}{l}\text { Risk mitigation measures are to be } \\
\text { implemented within the timeframe } \\
\text { specified }\end{array}$ \\
\hline Up to 100 & Allowable & $\begin{array}{l}\text { General rules on labour protection } \\
\text { are to be adhered to }\end{array}$ \\
\hline
\end{tabular}

To determine the risk, we define a matrix whose terms correspond to different levels of probability, and columns to different levels of loss. Cells in the matrix contain risk values. In the future, to simplify calculations, we will consider only three levels of probability and loss - minimum (1), medium (2) and high (3). 
We will set a risk management task - to reduce risk with minimal cost. Risk reduction is achieved through measures of two types. The first type of action reduces the probability of an unwanted event, and the second type reduces losses when an unwanted event occurs. We assume, first, that measures of the first and second types do not overlap. Let there be $n$ measures of the first type. Let us denote $a_{i}$ as the decrease in probability of $p$ during the $i^{\text {th }}$ event, $b_{i}$ - as the cost of hosting the $i^{\text {th }}$ event. Next, we denote $A_{1}$ as the magnitude of the reduction in the probability required to translate this indicator into the minimum risk category, $A_{2}-$ as the magnitude of reduction in probability required to transfer the indicator into the medium risk category. Let $x_{i}=1$, if the $i^{\text {th }}$ event is under risk reduction program, $x_{i}=0$ otherwise.

Task formulation:

To determine $x_{i}, i=\overline{1, n}$, such that $\sum_{i} b_{i} x_{i} \rightarrow$ min, with restrictions $\sum_{i} a_{i} x_{i} \geq A_{1}$.

This is the knapsack problem [20], which is effectively solved by dichotomous programming method at integer parameter values. Fig. 1 shows the structure of the dichotomous representation of the problem. The vertices $x_{1}-x_{6}$ match the set of measures. There is a matrix convolution of the corresponding lower-level indicators at vertices $y_{1}-y_{5}$

Solving this type of problem for each factor yields the cost $c_{i i}^{b}$, required to reduce probability from high level to $j=1,2,3$. In this case, value of $c_{i 3}^{b}$ matches the cost of maintaining a high level of risk (to prevent catastrophe).

Similar tasks are solved to determine the minimum cost of $c_{i i}^{y}$, required to reduce the amount of damage to the minimum or medium level.

Risk mitigation algorithm:

1. We determine the minimum cost of achieving each of the estimates using a matrix convolution. The first number in the matrix is value of the estimate, the second is the cost to achieve (or save) this estimate. Moving from the bottom up, we get minimal costs for each assessment (reducing the risk from high to medium and low). To do this, from the cells of the matrix with the same estimates (the first number), we select the cell with the lowest cost (the second cell).

2. The program variant formation, that is combination of factor assessments which provide the necessary value of integral estimate with the minimum costs, is carried out by reverse method. To do this, sequentially, from top to bottom, we determine which outputs match the selected cell of the matrix. By setting these values, we find them in the lower-level matrices.

We repeat this until we reach the lower level of dichotomous representation structure, that is specific estimates of risk factors. The set of these estimates is the result of the algorithm

Results. The research on hazard identification and risk assessment was conducted at the foundry shop of "Elekrtovazhmash" plant with the assistance of responsible occupational health professionals. The results of the analysis of hazard identification, risk assessment and management are formalized in

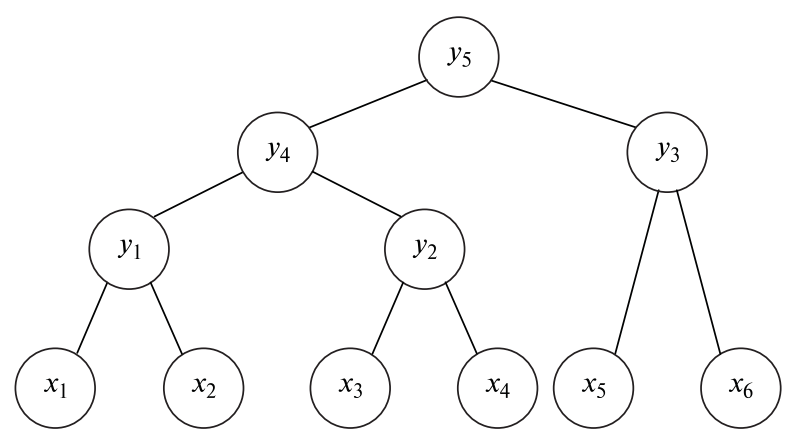

Fig. 1. Structure of a dichotomous task representation form of the "Register of Hazards and Risk Assessment" [19], a fragment of which is given in Table 6 .

Based on the analysis of register, the classification of risks according to their sources of origin was made. A few hazards have been identified as having the highest risk values and being most common (Fig. 2), and classification results are summarized in Table 7.

Thus, the most common risks are injuries from falling from a height (35\%), injuries from moving equipment (32\%), and injuries from electric shock (14\%). But the most serious are dangers of poisoning.

There are 6 measures to reduce the risk of the above hazards and corresponding costs, data on which are given in Table 8 .

Let $A_{1}=0.7$ and $A_{2}=0.4$. The task is to minimize

$$
B(x)=25 x_{1}+23 x_{2}+10 x_{3}+22 x_{4}+14 x_{5}+16 x_{6} .
$$

With restrictions

$$
3 x_{1}+2 x_{2}+x_{3}+2 x_{4}+x_{5}+1 x_{6} \geq 7 \text {. }
$$

Let us consider the dichotomous representation structure of the problem shown in Fig. 1.

Step 1. We solve the problem for steps 1 and 2. The solutions are given in Table 9. The first number in the cell equals the decrease in probability (effect), and the second - the cost. The results are summarized in Table 10.

Step 2. We solve the problem for measures 3 and 4. The solution is given in Table 11. The results are summarized in Table 12 .

Step 3. We solve the problem for measures 5 and 6 . The solution is given in Table 13. The results are summarized in Table 14.

Step 4 . We solve the problem for combined measures $(1,2)$ and $(3,4)$. The solution is given in Table 15 . The results are summarized in Table 16.

Step 5 . We solve the problem for combined measures (1-4) and $(5,6)$. The solution is given in Table 17.

The optimal solution is the cell $(7 ; 75)$. To determine the solution, we use the reverse method. Cell $(7 ; 75)$ corresponds to option 4 of Table 16 and variant 3 of Table 14 .

Variant 3 in Table 14 corresponds to cell $(2 ; 28)$ in Table 13 , which defines the values of variables $x_{5}=1, x_{6}=1$.

Variant 4 in Table 16 corresponds to cell $(5 ; 47)$ in Table 15. Cell $(5 ; 47)$ of Table 15 corresponds to variant 2 of Table 12 and variant 1 of Table 10 . Variant 2 of Table 12 corresponds to cell $(2 ; 22)$ of Table 11 , which determines values of the variables $x_{3}=0, x_{4}=1$.

Variant 1 of Table 10 corresponds to cell $(3 ; 25)$ of Table 9 , which determines values of variables $x_{1}=1, x_{2}=0$

We finally get the solution

$$
x_{1}=1 ; \quad x_{2}=0 ; \quad x_{3}=0 ; \quad x_{4}=1 ; \quad x_{5}=1 ; \quad x_{6}=1,
$$

which reduces probability by 0.7 with a minimum cost of 75 .

We will note that at the same time we have solved the problem of probability reduction, enough to transfer corresponding criterion with medium risk. Indeed, the optimal solution in this case corresponds to cell $(4 ; 35)$ of Table 17 . This cell corresponds to variant 2 of Table 16 and variant 0 of Table 14 . Variant 0 of Table 14 corresponds to cell $(0 ; 0)$ of Table 13 , that is $x_{5}=0$ and $x_{6}=0$. Variant 2 of Table 16 corresponds to cell ( 4 ; 35 ) of Table 15. Tis cell correspond to variant 1 of Table 12 and variant 1 of Table 10, that is, $x_{1}=1, x_{2}=0, x_{3}=1, x_{4}=0$.

Finally, we get the solution

$$
x_{1}=1 ; \quad x_{2}=0 ; \quad x_{3}=1 ; \quad x_{4}=0 ; \quad x_{5}=0 ; \quad x_{6}=0,
$$

which gives a probability reduction of 0.4 with a minimum cost of 35 .

We construct a convolution tree of risk indicators, Fig. 3.

To begin with, we combine fall-related injuries and injuries from moving equipment (I) and injuries from noise, vibration and injury from electric shock (II), which unite into the risks of mechanical impact (III). Then we combine poisoning and thermal burns (IV). Finally, we combine mechanical and ther- 
Fragment of the risk register form and risk assessment

\begin{tabular}{|c|c|c|c|c|c|c|c|c|c|c|c|c|c|c|c|}
\hline \multirow{2}{*}{$\begin{array}{l}\text { Type of } \\
\text { work }\end{array}$} & \multirow{2}{*}{$\begin{array}{l}\text { Operations, } \\
\text { materials, } \\
\text { equipment, } \\
\text { and others }\end{array}$} & \multirow{2}{*}{ Dangers } & \multirow{2}{*}{$\begin{array}{l}\text { Conditions of } \\
\text { occurrence }\end{array}$} & \multirow{2}{*}{ Risk } & \multicolumn{4}{|c|}{ Risk assessment } & \multirow{2}{*}{ 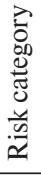 } & \multirow{2}{*}{$\begin{array}{l}\text { Measures/ } \\
\text { preventive } \\
\text { actions }\end{array}$} & \multicolumn{4}{|c|}{ Risk assessment } & \multirow{2}{*}{ 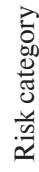 } \\
\hline & & & & & $P$ & $k_{2}$ & $k_{1}$ & $R$ & & & $P$ & $k_{2}$ & $k_{1}$ & $R$ & \\
\hline $\begin{array}{l}\text { Work at } \\
\text { height }\end{array}$ & $\begin{array}{l}\text { Foundry } \\
\text { equipment }\end{array}$ & $\begin{array}{l}\text { Location of } \\
\text { work-place at } \\
\text { height }\end{array}$ & Accident & Injury & 10 & 3 & 6 & 180 & 3 & $\begin{array}{l}\text { Equipment with } \\
\text { safety fence }\end{array}$ & 6 & 3 & 3 & 54 & D \\
\hline \multicolumn{16}{|l|}{$\ldots$} \\
\hline $\begin{array}{l}\text { Loading } \\
\text { and } \\
\text { unloadding } \\
\text { works }\end{array}$ & $\begin{array}{l}\text { Cranes and } \\
\text { mechanisms, } \\
\text { electric bridge } \\
\text { cranes }\end{array}$ & $\begin{array}{l}\text { Electric current } \\
\text { that can pass } \\
\text { through the body }\end{array}$ & Accident & $\begin{array}{l}\text { Electric } \\
\text { shock }\end{array}$ & 3 & 7 & 6 & 126 & 3 & $\begin{array}{l}\text { Safety signs, } \\
\text { neutral wire } \\
\text { earthing, double } \\
\text { cable isolation }\end{array}$ & 1 & 7 & 6 & 42 & D \\
\hline
\end{tabular}

Table 7

Classification of production risks of the foundry

\begin{tabular}{|c|c|c|c|c|c|}
\hline \multicolumn{6}{|c|}{ Kind of risk } \\
\hline $\begin{array}{c}\text { Injury from falling from } \\
\text { height }\end{array}$ & $\begin{array}{c}\text { Injury from moving } \\
\text { equipment }\end{array}$ & $\begin{array}{l}\text { Noise and } \\
\text { vibration }\end{array}$ & Injury from electric shock & $\begin{array}{c}\text { Poisoning, } \\
\text { occupational diseases }\end{array}$ & Thermal burns \\
\hline \multicolumn{6}{|c|}{ Causes of danger } \\
\hline $\begin{array}{l}\text { location of the workplace } \\
\text { at a considerable height } \\
\text { relative to the ground } \\
\text { (floor) }\end{array}$ & $\begin{array}{l}\text { moving parts of } \\
\text { production } \\
\text { equipment, moving } \\
\text { materials }\end{array}$ & $\begin{array}{l}\text { noise and } \\
\text { vibration }\end{array}$ & $\begin{array}{l}\text { increasing voltage in the } \\
\text { electrical network; } \\
\text { current that can pass } \\
\text { through the human body }\end{array}$ & $\begin{array}{l}\text { increased air pollution } \\
\text { and dustiness of the } \\
\text { work area }\end{array}$ & $\begin{array}{l}\text { the influence of } \\
\text { heated metal surfaces }\end{array}$ \\
\hline \multicolumn{6}{|c|}{ Type of works and equipment } \\
\hline $\begin{array}{l}\text { unloading and loading } \\
\text { works on cranes }\end{array}$ & $\begin{array}{l}\text { loading and } \\
\text { unloading works }\end{array}$ & $\begin{array}{l}\text { blasting } \\
\text { production } \\
\text { equipment }\end{array}$ & $\begin{array}{l}\text { work on existing electrical } \\
\text { installations; } \\
\text { lifting machines; } \\
\text { assembly and maintenance } \\
\text { work }\end{array}$ & $\begin{array}{l}\text { working with } \\
\text { equipment for thermal } \\
\text { work }\end{array}$ & $\begin{array}{l}\text { works on maintenance } \\
\text { and repair of } \\
\text { technological } \\
\text { equipment }\end{array}$ \\
\hline \multicolumn{6}{|c|}{ Protection measures } \\
\hline $\begin{array}{l}\text { arrangement of the } \\
\text { workplace with a } \\
\text { protective fence; } \\
\text { safety signs; } \\
\text { work on a ladder with a } \\
\text { safety belt }\end{array}$ & $\begin{array}{l}\text { protective fence; } \\
\text { safety signs }\end{array}$ & safety signs & $\begin{array}{l}\text { check of resistance of an } \\
\text { electric network, resistance } \\
\text { of isolation, grounding; } \\
\text { neutral wire earthing, use } \\
\text { of double insulated cable; } \\
\text { safety signs; } \\
\text { work in PPE }\end{array}$ & $\begin{array}{l}\text { arrangement of } \\
\text { exhaust ventilation; } \\
\text { PPE }\end{array}$ & $\begin{array}{l}\text { use of ventilation; } \\
\text { safety signs; } \\
\text { PPE }\end{array}$ \\
\hline
\end{tabular}

Table 8

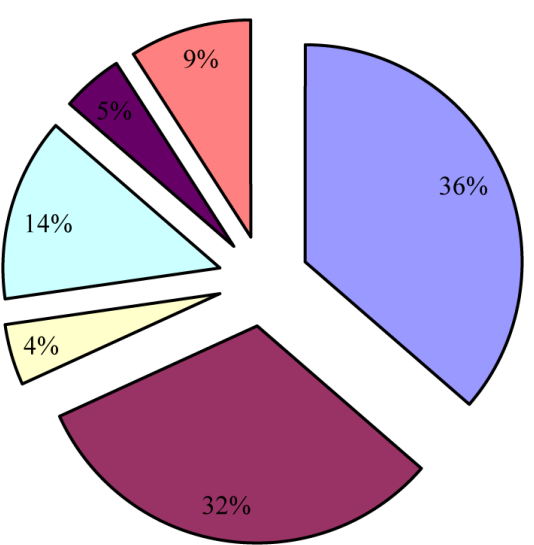

口Injury from falling from height

口Injury from moving equipment

$\square$ Noise and vibration

口Injury from electric shock

- Poisoning, occupational diseases

口Thermal burns

Fig. 2. Distribution of risks at the foundry
Measures to mitigate the risk of hazards and their associated costs

\begin{tabular}{|c|c|c|c|c|c|c|}
\hline$i$ & 1 & 2 & 3 & 4 & 5 & 6 \\
\hline$a_{i} \cdot 10$ & 3 & 2 & 1 & 2 & 1 & 1 \\
\hline$b_{i}$ & 25 & 23 & 10 & 22 & 14 & 16 \\
\hline
\end{tabular}

Table 9

Problem solving for measures 1 and 2

\begin{tabular}{|c|c|c|}
\hline 1 & $2 ; 23$ & $5 ; 48$ \\
\hline 0 & $0 ; 0$ & $3 ; 25$ \\
\hline $2 / 1$ & 0 & 1 \\
\hline
\end{tabular}

Computational results

Table 11

Problem solving for measures 3 and 4

\begin{tabular}{|c|c|c|}
\hline 1 & $2 ; 22$ & $3 ; 32$ \\
\hline 0 & $0 ; 0$ & $1 ; 10$ \\
\hline & 0 & 1 \\
\hline
\end{tabular}

\begin{tabular}{|l|c|c|c|c|}
\hline $\begin{array}{c}\text { Variant } \\
\text { number }\end{array}$ & 0 & 1 & 2 & 3 \\
\hline effect & 0 & 3 & 2 & 5 \\
\hline costs & 0 & 23 & 23 & 48 \\
\hline
\end{tabular}

Table 12

Computational results

\begin{tabular}{|c|c|c|c|c|}
\hline $\begin{array}{c}\text { Variant } \\
\text { number }\end{array}$ & 0 & 1 & 2 & 3 \\
\hline effect & 0 & 1 & 2 & 3 \\
\hline costs & 0 & 10 & 22 & 32 \\
\hline
\end{tabular}


Table 13

Problem solving for measures 5 and 6

\begin{tabular}{|c|c|c|}
\hline 1 & $1 ; 16$ & $2 ; 28$ \\
\hline 0 & $0 ; 0$ & $1 ; 14$ \\
\hline & 0 & 1 \\
\hline
\end{tabular}

\begin{tabular}{|c|c|c|c|c|}
\hline $\begin{array}{c}\text { Variant } \\
\text { number }\end{array}$ & 0 & 1 & 2 & 3 \\
\hline effect & 0 & 1 & 1 & 2 \\
\hline costs & 0 & 14 & 16 & 28 \\
\hline
\end{tabular}

Table 15

The problem for combined measures $(1,2)$ and $(3,4)$

\begin{tabular}{|c|c|c|c|c|}
\hline 3 & $3 ; 22$ & $6 ; 57$ & $5 ; 55$ & $8 ; 80$ \\
\hline 2 & $2 ; 22$ & $5 ; 47$ & $4 ; 45$ & $7 ; 70$ \\
\hline 1 & $1 ; 10$ & $4 ; 35$ & $3 ; 33$ & $6 ; 58$ \\
\hline 0 & 0 & $3 ; 25$ & $2 ; 23$ & $5 ; 78$ \\
\hline$(1,2) \quad(3,4)$ & 0 & 1 & 2 & 3 \\
\hline
\end{tabular}

Table 16

Computational results

\begin{tabular}{|c|c|c|c|c|c|c|c|c|}
\hline Variant number & 0 & 1 & 2 & 3 & 4 & 5 & 6 & 7 \\
\hline effect & 0 & 1 & 4 & 2 & 5 & 4 & 5 & 8 \\
\hline costs & 0 & 10 & 35 & 22 & 47 & 45 & 55 & 80 \\
\hline
\end{tabular}

Table 17

The results of the problem for combined measures $(1,2,3,4)$ and $(5,6)$

\begin{tabular}{|c|c|c|c|c|c|c|c|c|}
\hline 3 & $2 ;$ & $3 ;$ & $6 ;$ & $3 ;$ & $7 ;$ & $6 ;$ & $7 ;$ & - \\
& 28 & 38 & 63 & 50 & 75 & 73 & 83 & \\
\hline 2 & $1 ;$ & $2 ;$ & $5 ;$ & $3 ;$ & $6 ;$ & $5 ;$ & $6 ;$ & - \\
& 14 & 24 & 49 & 36 & 61 & 59 & 69 & \\
\hline 1 & $1 ;$ & $2 ;$ & $5 ;$ & $3 ;$ & $6 ;$ & $5 ;$ & $6 ;$ & - \\
& 16 & 26 & 51 & 38 & 63 & 61 & 71 & \\
\hline 0 & 0 & $1 ;$ & $4 ;$ & $2 ;$ & $5 ;$ & $4 ;$ & $5 ;$ & $8 ;$ \\
& & 10 & 35 & 22 & 47 & 45 & 55 & 80 \\
\hline$(5,6)$ & 0 & 1 & 2 & 3 & 4 & 5 & 6 & 7 \\
\hline
\end{tabular}

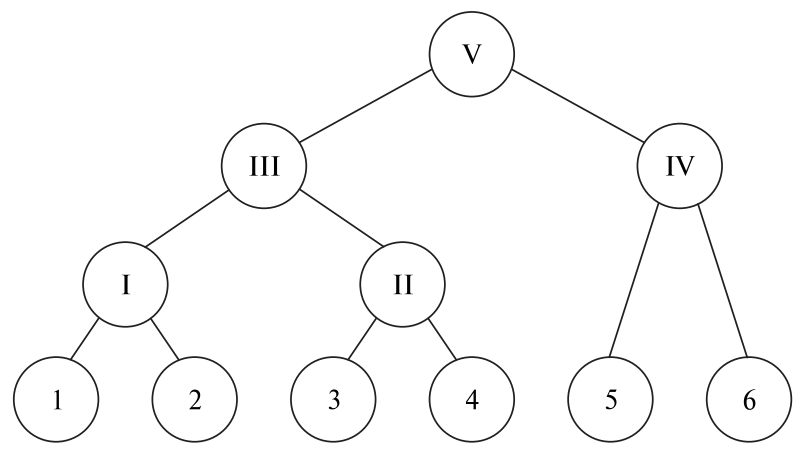

Fig. 3. Risk convolution tree

mochemical risks $(\mathrm{V})$ and obtain an integrated hazard reduction assessment.

Conclusions. Industrial risk management is associated with material costs of the enterprise for occupational safety measures. The approach proposed does not require the use of large amounts of statistics and complies with current international standards for health management and occupational safety. Thus, in the work:

1) methodology has been improved, risks of the "Elektrovazhmash" foundry have been identified and analysed;
2) for the first time, to optimize the costs of occupational safety measures in the machine-building enterprise unit, the "knapsack problem" was used, which allows reducing the amount of risk to the acceptable level.

\section{References.}

1. Bochkovskyi, A.P. (2018). Actualization of the scientific principles elaboration on evaluating the risks of occupational danger occurrence. Naukovyi Visnyk Natsionalnoho Hirnychoho Universytetu, (6), 95-103. https://doi.org/10.29202/nvn$\mathrm{gu} / 2018-6 / 14$.

2. Didenko, Ye. V. (2017). Model of risk assessment of industrial injury. Current state of research and technology in industry, 1(1), 28-33.

3. Tretyakov, O.V., Kharchenko, I.P., \& Pikhota, Ya.S. (2015). Increasing the reliability of indicators of the statistical method of assessing occupational injuries. Scientific and Technical Collection "Municipal Utility of Cities”, (120), 69-74.

4. Zaiats, Ye. I., Kravchunovska, T. S., Kovalov, V.V., \& Kirnos, O. V. (2018). Risk level assessment while organizationalmanagerial decision making in the dynamic external environment condition. Naukovyi Visnyk Natsionalnoho Hirnychoho Universytetu, (2), 123-129. https://doi.org/10.29202/nvngu/2018-2/24.

5. Bashynska, I. O., Poleshchuk, A.A., \& Motova, A.V. (2017). Improvement of the risk management system at the enterprise. Prychornomorski ekonomichni studiyi, (17), 91-94.

6. Cheberiachko, I.S., Yavorskyi, A.V., Yavorska, O.O., \& Tykhonenko, V.V. (2018). Evaluating the risks of occupational respiratory diseases of coal mine worker. Naukovyi Visnyk Natsionalnoho Hirnychoho Universytetu, (6), 104-111. https://doi. org/10.29202/nvngu/2018-6/13.

7. Vitkin, L. M., \& Rolko, O. R. (2016). Risks in management systems. Systemy obrobky informatsiyi, (3), 203-208.

8. Hlyva, V.A., Berezutskyy, V.V., Berezutska, N. L., \& Khalil, V.V. (2016). Audit of workplace safety risks. Tekhnologicheskii audyt i rezervy proizvodstva, (3), 12-17.

9. Yeromin, O.V., Deyneko, N.V., \& Strilets, V. M. (2014). Development of models for long-term prognosis of occupational risk level. Problemy nadzvychaynykh sytuatsiy. Zbirka naukovykh prats, (20), 44-52.

10. Kruzhylko, O. Ye., Storozh, Ya. B., Bohdanova, O. V., \& Polukarov, O. I. (2016). Planning of measures to reduce production risk using the Hurwitz criterion. Problemy okhorony pratsi $v$ Ukrayini, (32), 16-23.

11. Levchenko, O. H., \& Ilchuk, O.S. (2016). Analysis and assessment of the status of occupational injuries in the field of mechanical engineering. Visnyk Natsionalnoho Tekhnichnoho Universytetu Ukraiiny “Kyivskyi Politekhnichnyi Instytut”. Seriia: Hirnytstvo, (30), 171-176.

12. Lys, Yu. S. (2016). Risk assessment in the management of occupational safety. Systemy obrobky informatsiyi, (9), 193-196. 13. Tsybulska, O. V., \& Nepohodyev, S. V. (2014). Determination of probabilities for injuries resulting from an industrial accident. Problemy okhorony pratsi v Ukraini, (27), 111-119.

14. Tretyakov, O.V., Nestereko, S.V., Doronin, Ye.V., \& Holovenko, M. M. (2018). A risk-oriented approach to determining working conditions in the workplace. Stroitelstvo, $m a-$ terialovedenie, mashynostroenie. Seriia: Bezopasnost zhyznedeiatelnosti, (105), 131-138. https://doi.org/10.30838/P. CMM.2415.250918.126.142.

15. Vahonova, O. H., \& Kasyanenko, L. V. (2013). Estimation of the amount of damage prevented as a result of the implementation of emergency measures. Ekonomichnyi Visnyk Natsionalnoho Hirnychoho Universytetu, (2), 100-106.

16. Bezsonnyi, V. L. (2018). Mathematical modeling while ensuring safe working conditions. Bezpeka zhyttia i diialnosti liudyny - osvita, nauka, praktyka. Materialy Mizhnarodnoii naukovo-metodychnoii konferentsii, (pp.101-102). Lviv.

17. ISO 45001:2018 (2018). Occupational health and safety management systems - Requirements with guidance for use. 
18. Murtonen, M. (2012). Risk assessment in the workplace - a practical tool. Experience in Finland. Kyiv.

19. Recommendations on the Construction, Implementation and Improvement of the Occupational Safety Management System (2008).

20. Kupriiashyn, M.A., \& Borzunov, H.Y. (2014). Reducing the time complexity of a basic algorithm for solving a backpack problem. Bezopasnost informatsionnykh tekhnolohii, 21(1), 28-29.

\section{Управління виробничим ризиком у ливарному цеху}

\section{В. Л. Безсонний , О. В. Третьяков ${ }^{2}$, В. В. Асоцькийㄱ, Р. В. Пономаренко}

1 - Харківський національний економічний університет імені С. Кузнеця, м. Харків, Україна, e-mail: vitalii. bezsonnyi@hneu.net

2 - Харківська державна академія фізичної культури, м. Харків, Україна

3 - Національний університет цивільного захисту України, м. Харків, Україна

Мета. Підвищення ефективності управління виробничими ризиками підрозділу машинобудівного підприємства шляхом: 1) удосконалення методики аналізу існуючих ризиків; 2) розробки програми оптимізації витрат при управлінні ризиками.

Методика. У дослідженні були використані загальнонаукові та спеціальні методи дослідження: аналіз, узагальнення наукового досвіду; оцінка ризиків і небезпек проводилася 3 використанням методу структурованої оцінки; при вирішенні задачі оптимізації витрат використовувалася модель «пакування рюкзака».

Результати. Оскільки управління виробничими ризиками пов'язано з матеріальними витратами підприємства на заходи з охорони праці, підвищення ефективності управління ризиками полягає у послідовному використання якісних та кількісних оцінок. Удосконалена методика, ідентифіковані та проаналізовані наявні небезпечні чинники, поставлені та вирішені задачі щодо оптимізації витрат при управлінні ризиками.

Наукова новизна. Полягає у використанні при управлінні ризиками вдосконаленого підходу до їх оцінки та використання оптимізаційної моделі. Дістали подальшого розвитку методичні підходи до оцінки ризику, що полягають у включенні до розрахунку не тільки ймовірності виникнення. Уперше для оптимізації витрат на заходи з охорони праці в підрозділі машинобудівного підприємства використана задача «пакування рюкзака» шо дозволяє знизити величину ризику до допустимого рівня.

Практична значимість. Результати дослідження втілені в конкретну методику, використання якої дозволяе оптимальним чином здійснювати управління ризиками в підрозділі підприємства.
Ключові слова: управління ризиком, виробничий ризик, модель «пакування рюкзака», машинобудування

\section{Управление производственным риском в литейном цехе}

\section{В. Л. Бессонный느, О. В. Третьяков ${ }^{2}$, В. В. Асоикий ${ }^{3}$, Р. В. Пономаренко}

1 - Харьковский национальный экономический университет имени С. Кузнеца, г. Харьков, Украина, e-mail: vitalii.bezsonnyi@hneu.net

2 - Харьковская государственная академия физической культуры, г. Харьков, Украина

3 - Национальный университет гражданской защиты Украины, г. Харьков, Украина

Цель. Повышение эффективности управления производственными рисками подразделения машиностроительного предприятия путем: 1) совершенствования методики анализа существующих рисков; 2) разработки программы оптимизации затрат при управлении рисками.

Методика. В исследовании были использованы общенаучные и специальные методы исследования: анализ, обобщение научного опыта; оценка рисков и опасностей проводилась с использованием метода структурированной оценки; при решении задачи оптимизации расходов использовалась модель «упаковки рюкзака».

Результаты. Поскольку управление производственными рисками связано с материальными затратами предприятия на мероприятия по охране труда, повышение эффективности управления рисками заключается в последовательном использования качественных и количественных оценок. Усовершенствована методика, идентифицированы и проанализированы имеющиеся опасные факторы; поставлены и решены задачи по оптимизации расходов при управлении рисками.

Научная новизна. Заключается в использовании при управлении рисками усовершенствованного подхода к их оценке и использовании оптимизационной модели. Получили дальнейшее развитие методические подходы к оценке риска, которые заключаются во включении в расчет не только вероятности возникновения. Впервые для оптимизации затрат на мероприятия по охране труда в подразделении машиностроительного предприятия использована задача «упаковки рюкзака», что позволяет снизить величину риска до допустимого уровня.

Практическая значимость. Результаты исследования воплощены в конкретную методику, использование которой позволяет оптимальным способом осуществлять управление рисками в подразделении предприятия.

Ключевые слова: управление риском, производственный риск, модель «упаковки рюкзака», машиностроение

Recommended for publication by V. Strilets, Doctor of Technical Sciences. The manuscript was submitted 13.02.19. 